STATE OF ILLINOIS

DWIGHT H. GREEN, Governor

DEPARTMENT OF REGISTRATION AND EDUCATION

FRANK G. THOMPSON, Director

DIVISION OF THE

STA TE GEOLOGICAL SURVEY

M. M. LEIGHTON, Chief

URBANA

REPORT OF INVESTIGATIONS-NO. 122

UPPER KINKAID (MISSISSIPPIAN) MICROFAUNA FROM JOHNSON COUNTY, ILLINOIS

BY

CHALMER L. COOPER

- Reprinted from the Journal of Paleontology, Vol. 21, No. 2, MARCH, 1947

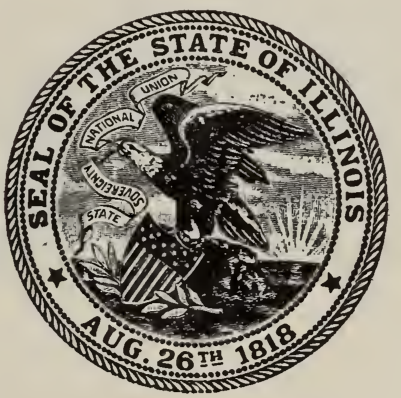

PRINTED BY AUTHORITY OF THE STATE OF ILLINOIS

URBANA, ILLINOIS 


\title{
ORGANIZATION
}

\author{
STATE OF ILLINOIS \\ HON. DWIGHT H. GREEN, Governor \\ DEPARTMENT OF REGISTRATION AND EDUCATION \\ HON. FRANK G. THOMPSON, Director
}

\author{
BOARD OF NATURAL RESOURCES AND CONSERVATION \\ HON. FRANK G. THOMPSON, Chaiman \\ W. H. NEWHOUSE, Ph.D.. Geology \\ ROGER ADAMS, Pir.D., D.Sc., Chemistry \\ LOUIS R. HOWSON, C.E., Engincering \\ CARL G. HARTMAN, Pr.D., Biology' \\ LEWIS H. TIFFANY, PII.D., Forestry' \\ GEORGE D. STODDARD, Ph.D., Litr.D., LL.D., L.H.D. \\ President of the University' of Illinois
}

GEOLOGICAL, SURVEY DIVISION

M. M. LEIGHTON, Chief 


\title{
SCIENTIFIC AND TECHNICAL STAFF OF THE STATE GEOLOGICAL SURVEY DIVISION
}

\author{
100 Natural Resources Building, Urbana
}

M. M. LEIGHTON, Pн.D., Chief

Enid Townley, M.S., Assistant to the Chie

Velda A. Millard, Junior Asst, to the Chief

\section{GEOLOGICAL RESOURCES}

RAlPH E. GRIM, PH.D., Petrographer and Principal Geologist in Charge

Coal

G. H. CADY, PH.D., Senior Geologist and Head R. J. Helfinstine, M.S., Mech. Engineer Rolf W. Roley, B.S., Asst. Mining Engineer Robert iI. Kosanke, M.A., Asst. Geologist Joiln A. Harrison, B.S., Asst. Geologist JaC K A. Simon, B.A., Asst. Geologist

AR Nold EDdings, B.A., Asst. Geologist

ArNold EDdings, B.A., Asst. Geologist

Margaret Parker, B.S., Research Assistant

Walter E. COOPER, Technical Assistant

Florence HoneA, B.F.A., Technical Assistant

Oil and Gas

A. H. Bell, Pr.D., Geologist and Head Frederick SouIRES, B.S., Petroleum Engineer

David H. Swan N, PH.D., Assoc. Geologist

Virginia Kline, Ph.D., Assoc. Geologist

Paul G. Luckhardt, M.'S., Asst. Geologist

IVAYne F. Meents, Asst. Geologist

RIChARD J. Cassin, B.S., Research Assistant

Nancy McDurmitt, B.S., Research Assistant

\section{Industrial Minerals}

J. E. LAMAR, B.S., Geologist and Head

Robert M. Grogan, Ph.D., Assoc. Geologist

Raymond S. Sirrode, B.S., Research Assistant

Clay Resources and Clay Mincral Technology

RAlPh E. GRIM, Ph.D., Petrographer and Head

Henry M. Putman, B.A.Sc., Asst. Geologist

William A. White, B.S., Research Assistant

Groundwater Geology and Geophysical

\section{Exploration}

CARL A. BAys, PH.D., Geologist and Engineer, and Head

Robert R. Storm, A.B., Assoc. Geologist

Arnold C. Mason, B.S., Assoc. Geologist (on leave)

Merlyn B. Buhle, M.S., Assoc. Geologist

M. W. Pullen, Jr., M.S., Asst. Geologist

Gordon W. Prescott, B.S., Asst. Geologist

Margaret J. Castle, Asst. Geologic Draftsman

Robert N. M. Urash, B.S., Research Assistant

GeORGE H. DAvis, B.S., Research Assistant (on leave)

\section{Engineering Geology and Topographic \\ Mapping}

Grorge E. Ekrlaw, Ph.D., Geologist and Head

RiChARD F. Fisher, M.S., Asst. Geologist

Areal Geology and Paleontology

H. B. Willman, Ph.D., Geologist and Head

Heinz A. Lowenstam, Ph.D., Assoc. Geologist

J. S. Templeton, Ph.D., Assoc. Geologist

Donald Saxby, M.S., Research Assistant

\section{Subsurface Geology}

L. E. Workman, M.S., Geologist and Head

Eiwood Atherton, Ph.D., Asst. Geologist

Paul Herbert, Jr., B.S., Asst. Geologist

Marvin P. MeYer,'M.S., Asst. Geologist

Physics

R. J. Piersol, Ph.D., Physicist Emeritus
HELEN E. MCMORris, Secretary to the Chief

Effie Hetishee, B.S., Geological Assistant

\section{Mineral Resource Records}

VIVIAN GoRDON, Head

Ruth R. Warden, B.S., Research Assistant

DOROTHY F. SPENCER, B.S., Technical Assistant

Mary BurnetT, Technical Assistant

Susan M. Tull, B.A., Technical Assistant

Meta L. Pilgrim, Technical Assistant

Harriet C. Daniels, B.A., Technical Assistant

\section{GEOCHEMISTRY}

Frank H. REeD, Ph.D., Chief Chemist

Grace C. Johnson, B.S., Research Assistant

Coal

G. R. Yoнe, PH.D., Chemist and Head

Eva O. Blodget T, B.S., Research Assistant

Industrial Minerals

J. S. MACHIN, PH.D., Chemist and Head

Tin BoO YEE, M.S., Research Assistant

Paulene Ekman, B.A., Research Assistant

Fluorspar

G. C. FINGER, PH.D., Chemist and Head

Oren F. Williams, B.Engr., Special Research Assistant Chemist

LEWIS E. MONCRIEF, B.S., Research Assistant

Horst G. SCHNeIder, B.S., Special Research Asst.

Chemical Engineering

H. W. JАскмал, M.S.E., Chemical Engineer and

P. Head Henline, M.S., Assoc. Chemical Engineer

B. J. Greenwood, B.S., Mechanical Engineer

James C. McCullough, Research Associate

James H. Hanes, B.S., Research Assistant

(on leave)

Earl C. Noble, Technical Assistant

$X$-ray and Spectrography

W. F. BradeEy, Ph.D., Chemist and Head

Analytical Chemistry

O. W. ReEs, Pr.D., Chemist and Head

L. D. MCVICKER, B.S., Chemist

Howard S. Clark, A.B., Assoc. Chemist

JoH N C. GoGley, B.S., Research Assistant

JoH N C. GOGLEY, PIERron, B.S., Research Assistant

Emile D. Pierron, B.S., Research Assistant

Albertine Krohn, B.S., Research Assistant

Gloria J. GILKEY, B.S., Research A ssistant

A N Nabelle G. Elliott, B.S., Technical Assistant

\section{MINERAL ECONOMICS}

W. H. Voskuil, Pri.D., Mincral Economist Douglas F. Stevens, M.E., Research Associate Nina Ham ick, A.B., Research Assistant

ETHEL M. KInG, Research Assistant

\section{EDUCATIONAL EXTENSION}

Gilbert O. RaAscit, Ph.D., Assoc. Geologist

Georgia B. Merediti, B.S., Technical Assistant

\section{LIBRARY}

REgINa YoAst, B.A., B.L.S., Librarian

RuBY D. Frison, Technical Assistant

\section{PUBLICATIONS}

Dorothy E. Rose, B.S., Technical Editor

M. Elizabet St Staks, B.S., Assistant Editor Meredith M. Calkins, Geologic Draftsman

Beverly Scotton, Assistant Geologic Draftsman

Witus L. Busch, Principal Technical Assistant

LFSIE D. VAUGHAN, Assistant Photographer

Beula it. Unfer, Technical Assistant

Consultants: Ceramics, Cullen W. Parmelee, M.S., D.Sc., and Ralph K. Hursh, B.S., University of Illinois Mechanical Engineering. SEICHI Konzo, M.S. University of Illinois

Topographic Mapping in Cooperation with the United States Geological Survey.

This report is a contribution of the Division of Areal Geology and Paleontology. 
Digitized by the Internet Archive in 2012 with funding from University of Illinois Urbana-Champaign 


\title{
UPPER KINKAID (MISSISSIPPIAN) MICROFAUNA FROM JOHNSON COUNTY, ILLINOIS
}

\author{
CHALMER L. COOPER \\ U. S. Geological Survey
}

\begin{abstract}
In northwestern Johnson County, Illinois, the Wayside formation (Lower Pennsylvanian) rests with apparently slight disconformity upon the Kinkaid formation (upper Chester). An important and varied microfauna, consisting of Foraminifera, ostracodes, and conodonts is described and compared with Morrow microfaunas from the Midcontinent and other areas. The Foraminifera include the genera Endothyra, Glomospira, Hyperammina, Palaeotextularia, Trepeilopsis, and Millerella. The last is specifically described from the Mississippian for the first time. Five genera of conodonts and 20 genera ( 35 species) of ostracodes are included in the fauna.
\end{abstract}

$\mathrm{T}_{\mathrm{b}}^{\mathrm{s}}$ HIS paper presents the microfauna from beds that are thought to be the youngest Chester in the area regarded as the type for the Mississippian system, where these beds could be examined and studied in relation to the superjacent Pennsylvanian. The type area for the Kinkaid formation is located along Kinkaid Creek, which cuts through the formation in NW. $\frac{1}{4}$ sec. 6, T. 8 S., R. $4 \mathrm{~W}$., Jackson County, Illinois. This is less than 15 miles southeast of the town of Chester and the locality from which the fauna in question was collected is about 40 miles southeast of Chester. All known outcrops of the Kinkaid in southern Illinois that might show the contact with the overlying Pennsylvanian were visited in order to obtain as much data as possible on the contact relations of the PennsylvanianMississippian boundary. The best section observed is that exposed on a north tributary of Lick Creek, which flows southeast across sec. 31, T. 11 S., R. 2 E., crossing the upper Kinkaid boundary in the northwest quarter of the section. This outcrop was described in detail by Lamar $(1925$, p. 80) who measured about 30 feet of Pottsville (Wayside) overlying 91 feet of the Kinkaid formation, the latter containing about onethird shale and two-thirds limestone. The details of the contact relations, modified somewhat from Lamar's subdivisions, are shown in figure 1.

A coral fauna from these beds was described by Easton (1945) who correlates the Kinkaid beds containing Kinkadia trigonalis, Triplophyllites palmatus, and Caninostrotion variabilis with the upper part of the Pitkin formation of western Arkansas. These corals were obtained from the massive limestone at the base of the section (fig. 1) and the thin limestones a short distance above it (between samples 2 and $5)$. Concerning the coral fauna he concluded (p. 384):

... the geographic distribution of the corals 


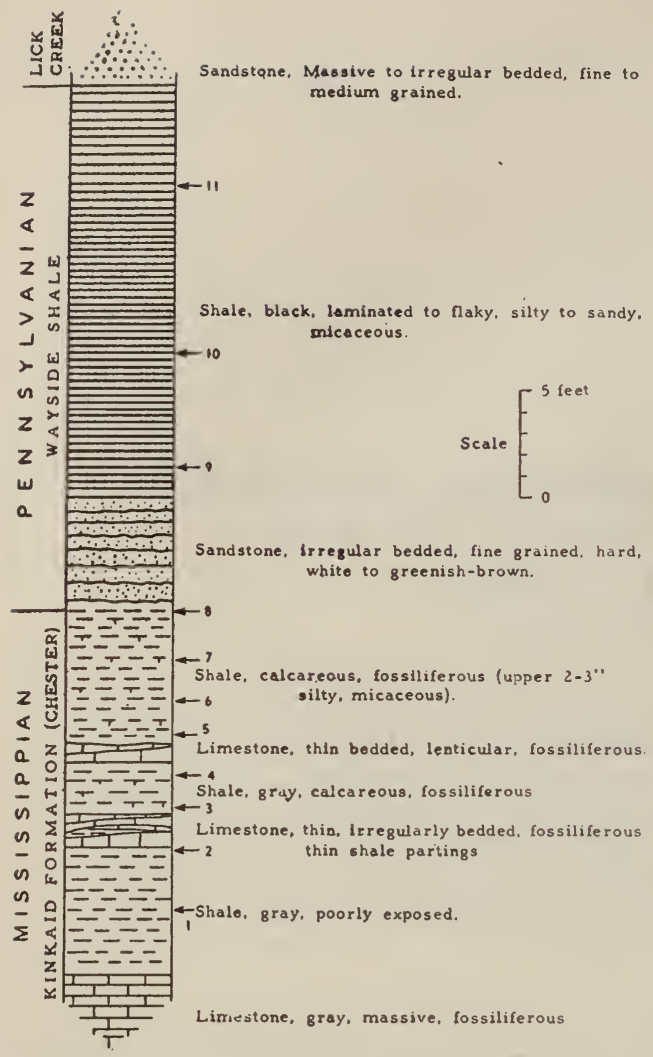

FIG. 1-Mississippian-Pennsylvanian contact in Johnson County, Illinois. The arrows to the right of the column show the approximate position of samples collected for study. The beds were sampled so that all zones from the top of the massive limestone at the bottom of the column to the base of the Lick Creek sandstone were collected.

sliows that the two basins (Arkansas and Illinois) were connected and that favorable ecologic conditions of unknown duration enabled faunal migration of some distinctive organisms.

All zones in the Kinkaid shales above the massive limestone shown at the base of the column in figure 1 contain a microfauna in varying amounts, principally ostracodes. However, the samples above and below the upper thin irregularly bedded limestone proved to be the most fruitful, zone 5 furnishing the fusulines which are described later. The Wayside shales above the Kinkaid are barren of fossils.

A short time ago the very primitive, short axis fusuline, Millerella, was described by Thompson (1942, p. 404). The holotype came from the type locality of the Marble Falls formation in Burnet County, Texas, and the paratypes were collected from the "Bend" series in the Hueco Mountains of

\section{Explanation of Plate 19}

FIgs. 1-5-Millerella chesterensis Cooper, n. sp. 1, 4, Saggital sections with endothyroid juvenaria, and irregular coiling as shown by the elongate volution and lack of continuity of the tunnel in the plane of the section, $\times 100.2,3$, Axial sections, showing modified hour-glass outline, $\times 100.5$, Enlargement of 1 to show details of coiling of first volution in a plane at right angles to the plane of the section, $\times 200$. Kinkaid formation, bed 5, Johnson County, Illinois.

(p. 85)

6-8-Millerella zelleri Cooper, n. sp. 6, 8, Sagittal sections showing uniformity of coiling and tunnel, the latter lying almost wholly in the plane of the section, $\times 100.7$, Axial section, $\times 100$. Kinkaid formation, bed 5 , Johnson County, Illinois.

(p. 86)

9, 11-Millerella kinkaidensis Cooper, n. sp. Sagittal and axial sections, the latter showing the relatively long axis and modified keel-like margin, $\times 100$. Kinkaid formation, bed 5 , Johnson County, Illinois.

10, 12-Millerella sp. External views of two specimens, $\times 60$.

(p. 86)

13-Millerella of M. pinguis Thompson Sagittal section, $\times 100$. Dornick Hills group,

T. 3 S., R. 2 E., Carter County, Oklahoma.

sec. 12 locality as fig. 13.

(p. 83)

16-17-Millerella advena Thompson. Sayittal and axial sections, the latter showing inflated character and eccentric coiling of early volution, $\times 100$. Lower Dornick Hills group, NW. $\frac{1}{4}$, NW. $\frac{1}{4}$, NE. $\frac{1}{4}$, sec. 16, T. 6 S., R. 2 E., Carter County, Oklahoma. (p. 83)

18-Millerella inflecta Thompson. Sagittal section from the Belden formation, bed 15, section P-15, Sweetwater Creek. Near Glenwood Springs, Colorado, X100. (Thompson, 1945, p. 44 , pl. 1, fig. 5.) 

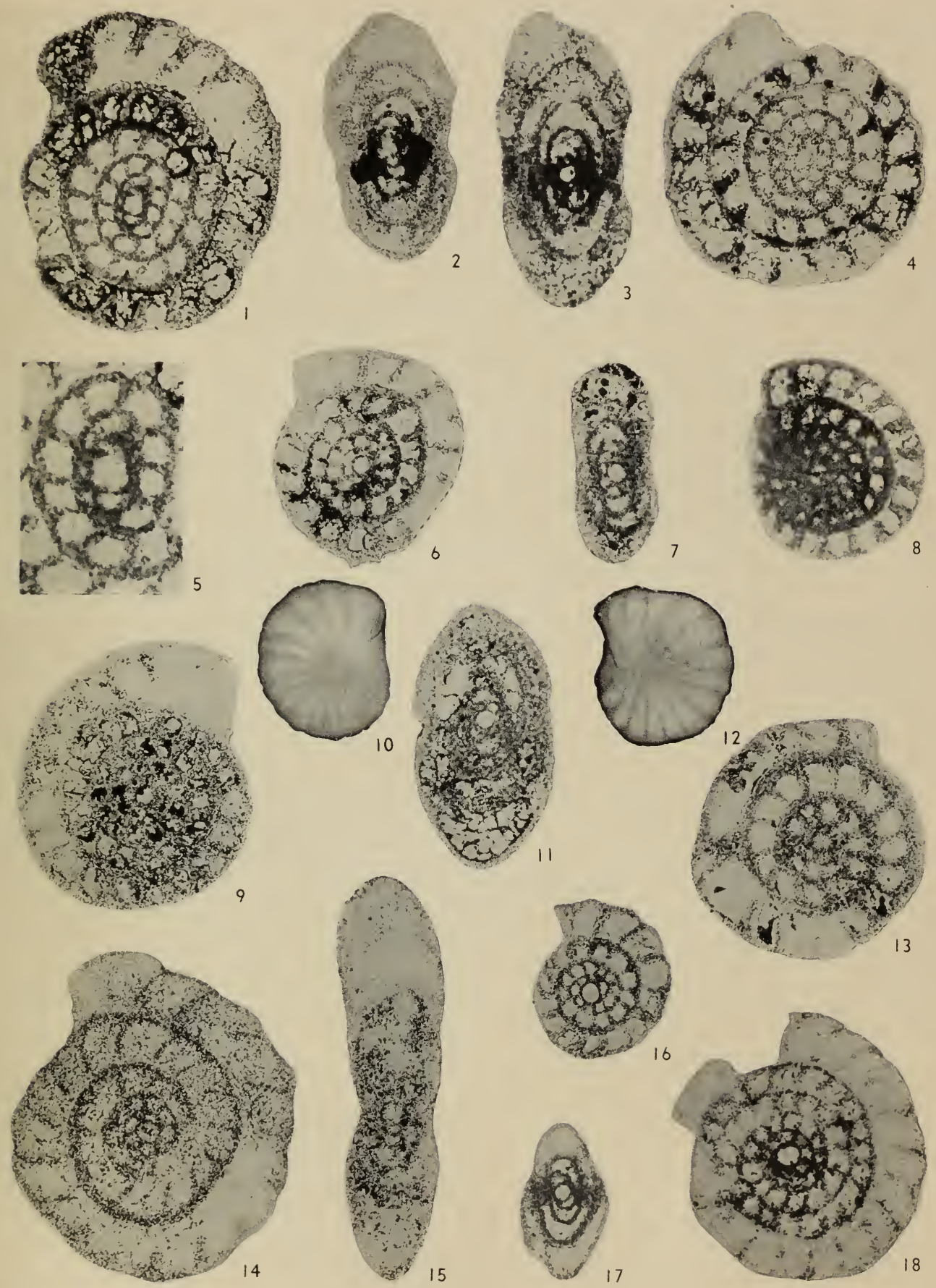

Cooper, Carboniferous Millerella

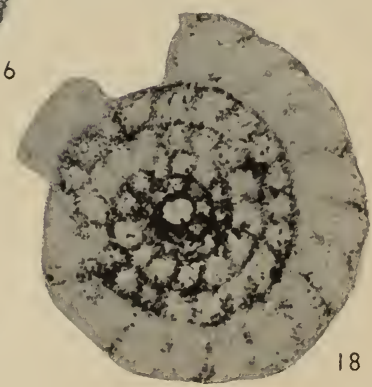




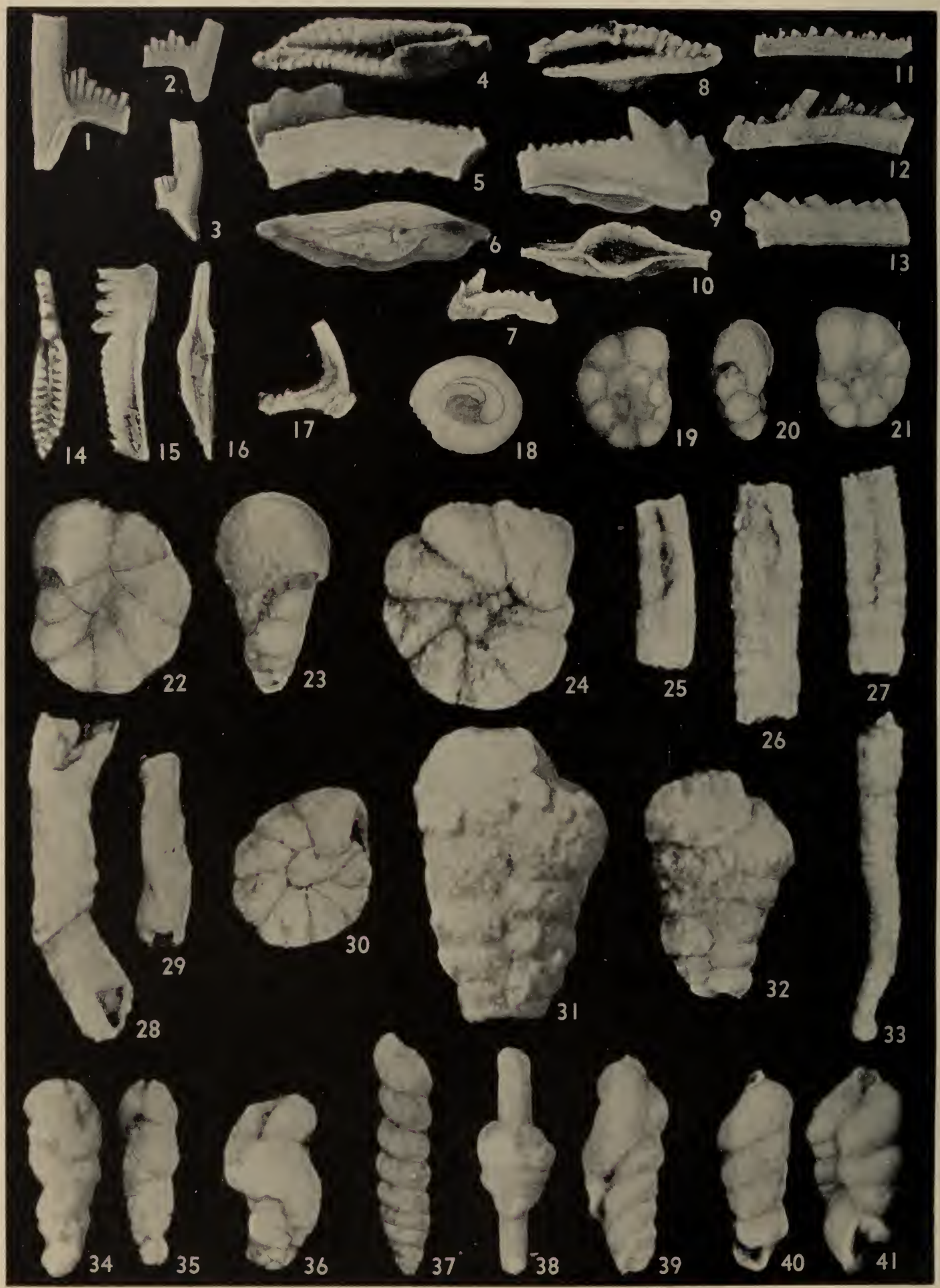

Cooper, Chester Conodonts and Foraminifera 
Texas and the Mud Springs Mountains in central New Mexico. Later, Thompson (1944, p. 420) discovered the genotype species, M. marblensis, in the Brentwood limestone at the well-known type section of the Morrow group in northwestern Arkansas, and defined the zone of Millerella as that part of the stratigraphic section containing this fusuline to the exclusion of the normal long-axis forms. He also stated that

It is entirely possible, if not probable, that species of Millerella or of a closely allied ancestral genus of fusulinids will be found in rocks of Mississippian age.

\section{Later (1945, p. 42) he stated that}

All fusulinids so far discovered in the Belden formation (Idaho) are referable to the genus Millerella, which was originally described from the upper part of the Marble Falls limestone of Texas. Congeneric species are known to occur stratigraphically from near the base of the Morrowan series to near the top of the Pennsylvanian system. It is probable that further study will demonstrate the occurrence of Millerella in rocks older than Morrowan.

Endothyra has long been considered by some as the progenitor of the fusulinids (Galloway, 1933, pp. 388, 393; Dunbar and Henbest, 1942, p. 52) but most fusuline students have considered that the true Fusulinidae were confined to the Penn- sylvanian and Permian. However, the recognition of Millerella in zones of the upper Chester in the type area demonstrates conclusively the occurrence of true fusulines in Mississippian rocks as Thompson predicted.

The thin sections of Chester Millerella were shown to Dr. Thompson at the Pittsburgh meeting of the Geological Society of America, and they were later sent to him for direct comparison with his described material. He states that "I have compared the specimens you sent me with all other similar forms I have in the laboratory. So far as I can tell they are more closely similar to the types of Millerella inflecta from the Belden formation of northwest Colorado."'1

There are, however, some important and easily recognized differences between the Chester forms (pl. 19, figs. 1-12) and those previously described (pl. 19, figs. 13-18), consequently the older forms are described as new species. These distinguishing features are as follows:

1. The very strongly rounded periphery.

2. The relatively short, straight septa rapidly widening near the outer wall and producing a structure which is $\Delta$-shaped in cross section (see sagittal sections), in contrast to the thin,

${ }^{1}$ Personal communication, January 27, 1946

\section{Explanation of Plate 20}

Figs. 1-3-Prioniodus scitulus Branson and Mehl. Lateral views, $\times 20$.

(p. 92) 4-10-Cavusgnathus cristata Branson and Mehl. Oral, aboral, and lateral views; 4-6, 8-10, $\times 20$; $7, \times 30$.

11-13-Hindeodella sp. Lateral views; $11, \times 20 ; 12,13, \times 30$.

14-16-Taphrognathus varians Branson and Mehl. Oral, lateral and aboral views, $\times 30$. (p. 92)

17-Ligonodina cf. L. levis Branson and Mehl. Lateral view, $\times 30$.

18-Glomospira disca Cooper, n. sp. Lateral view of holotype, $\times 60$.

(p. 91)

(p. 87)

19-23-Endothyra excentralis Cooper, n. sp. 19,21, Lateral views and 20, aperatural view of a young specimen; 22, lateral view of holotype showing involute right side and greatly enlarged final chamber; 23 , apertural view of holotype. $\times 60$.

(p. 88)

24, 30-Endothyra acuta Cooper, n. sp. Lateral views, $\times 60$. 24, Holotype, showing umbilicus, depressed sutures, and sharply curved outer margin of chambers, bed 5. 30, Smaller specimen showing highly arched aperture, bed 4 .

(p. 88)

25-27-Hyperammina cf. elongata clavulata Howchin. Lateral views of three fragmentary specimens, $\times 60$.

28, 29-Hyperammina sp. Lateral views, $\times 60$.

(p. 88)

$31,32-$ Palaeotextularia asper Cooper, n. sp. Lateral views, $\times 60.31$, Holotype.

(p. 89)

(p. 89)

33-Hyperammina cf. H. glabra Cushman and Waters. Lateral view of a nearly complete specimen, with initial chamber, $\times 50$.

34-41-Trepeilopsis mississippiana Cooper, n. sp., Lateral views, $\times 60.36,39,41$, Specimens showing tube bent back over earlier whorls; 38 , specimen coiled about a Productus spine; 37 , regular coils without development of straight portion. 34, 35, from bed $1 ; 36,38,40,41$, beds 5,$6 ; 37$, bed 7 ; and 39 , bed $4.40,41$, Two views of the holotype, showing wide, flaring aperture. 34,35 , Two views of a single specimen.

(p. 87) 
more strongly curved septa of Pennsylvanian species.

3. The eccentricity of coiling, particularly in earlier volutions.

4. The modified hour-glass shape as visible in axial sections and the variation in degree of concavity of the two sides.

5. The endothyroid juvenarium of some species.

Based upon differences of size of proloculum, height of volutions, form ratio, and septal count, three new species are recognized in the Kinkaid fauna, namely $M$. chesterensis (pl. 19, figs. 1-5), M. zelleri ( $\mathrm{pl}$. 19, figs. 6-8) and M. kinkaidensis (pl. 19, figs. 9, 11). In general the Chester species are intermediate in form between the two extremes from the Pennsylvanian, namely, M. marblensis and $M$. adrena (see sagittal sections), having thicker shells than the former and lacking the inflated umbilical area of the latter. While the number of chambers per volution are about the same, the shorter, thicker septa of the Mississippian forms result in proportionally smaller chambers.

Millerella (species undescribed) from the Pitkin (upper Chester) of Arkansas has been reported by Henbest (1946). Representatives of the genus are also known to occur with Chester species of Archimedes and trilobites in beds of the Amsden formation in Wyoming (Zeller, 1946, personal communication).

In addition to the fusulines several genera of smaller Foraminifera are present in the Kinkaid microfauna (pl. 20, figs. 23-26). There are two new species of Endothyra, one of which, $E$. acuta, is suggestive of $E$. whitesidei Galloway and Ryniker, known heretofore from the Atoka of Oklahoma and the Marble Falls of Texas. The other is similar to $E$. media Waters, E. rothrocki Harlton and E. distenta H. J. Plummer, from horizons in Oklahoma and Texas well above the Morrow zone and considerally younger than the Kinkaid. The flattened cylindrical forms with the irregularly spaced constrictions marking successive chamlers closely resemble those from the Johns Valley shale of Oklahoma described as IIyperammina elongata clavatula Howchin by Harlton (1933, p. 8). A species of Palaeotextularia is not like the Johns Valley species. The extremely irregularly coiled Trepeilopsis is abundant and shows the variable nature of these forms. This genus is known to occur as low as the Chouteau (or Rockford), although described species are restricted to the Pennsylvanian. Significant is the absence of such characteristically Pennsylvanian genera as Polytaxis, Tetrataxis, Endothyranella, and Reophax.

Chester and Morrow conodont literature consists of only one paper for each of these subdivisions (Branson and Mehl, 1940 and Harlton, 1933). The conodonts in the Kinkaid are strongly Mississippian in character containing none of the typically Pennsylvanian forms described by Harlton from the Johns Valley. The two species of Prioniodus, $P$. scitulus and $P$. varians, are not known from beds younger than Chester. A common Pennsylvanian genus, Cavusgnathus, is represented by $C$. cristata which is easily distinguished from younger species. The specimens of Hindeodella, while not identifiable specifically, possess denticulated bars similar to those described from the Caney shale. A species of Taphrognathus, not known heretofore above the Keokuk, gives a distinct Mississippian aspect to the Kinkaid fauna.

The ostracodes are of the greatest value for determining the age of this fauna. The literature contains two fairly complete papers describing Kinkaid ostracodes (Croneis and Thurman, 1938 and Cooper, 1942) and several additional papers describe other Chester faunas. Information on Lower Pennsylvanian ostracodes is contained largely in papers by Roth (1929) and Harlton $(1929,1933)$.

Plate 21 shows such typical upper Chester species as Balantoides reticulatus Croneis and Thurman (figs. 1-3), the three species of Bairdia, B. golcondensis Croneis and Gale (figs. 25, 26), B. attenuata (figs. 27, 28), and B. impendere Cooper (figs. 29, 30), Beyrichiopsis thori Coryell and Johnson (fig. 13 ), and the two species of Ectodemites, $E$. planus Cooper (figs. 9-12) and E. tumida Cooper (figs. 14-16). However, the Cornigella (figs. 4-6) is indistinguishable from $C$. tuberculospinosa (Jones and Kirkby) listed by Harlton as C. pushmatahensis in his Johns Valley fauna which has a long range in the Pennsylvanian. Also Amphissites insignis Corneis and Thurman (figs. 19-22), differs 
little from $A$. marginiferus Roth from the Union Valley and Wapanucka formations of Oklahoma.

Glyptopleurina iniqua (pl. 22, fig. 35) and Hollinella radiata (Jones and Kirkby) (figs. 20-23) are typical, easily recognized, and range no higher than the Chester. However, without close examination Glyptopleura similis Croneis and Funkhouser (figs. 32-34) might be confused quite easily with $G$. coryelli Harlton which has a long range in the Pennsylvanian. The species of Healdia are characteristically Chester.

Other good Chester markers, are Glyptopleura tyri Coryell and Johnson (pl. 23, figs. 9-11), Perprimitia funkhouseri Croneis and Thurman, (figs. 15-17), Polytylites quincollinus Harlton (fig. 25), and Sargentina crassimarginata Cooper (figs. 30-34). However, the reversed forms of Sansabella harrisi Croneis and Funkhouser (figs. 26-29) might easily be mistaken for $S$. carbonaria Cooper from the Pennsylvanian.

In summary, the fauna described is from the youngest Mississippian beds in the type area, which can be studied in connection with the Mississippian-Pennsylvanian contact. While predominantly Chester, the microfauna reflects other Chester faunal and sedimentological characteristics in that it heralds the approaching Pennsylvanian by showing a distinct break from the Middle Mississippian, while at the same time containing some early Pennsylvanian elements. All of the fauna, with the exception of the foraminifer Trepeilopsis and the ostracode Hollinella radiata show a complete lack of Middle or Lower Mississippian affinity, while most of the Foraminifera, including the fusuline Millerella, and some ostracodes and conodonts have a distinctly Pennsylvanian character.

\section{SYSTEMATIC DESCRIPTIONS}

Order Foraminifera d'Orbigny, 1826

Family Fusulinidae Möller, 1878

Genus Millerella Thompson, 1942

Millerella Thompson, 1942, Am. Jour. Sci., vol. 240, nc. 6, p. 404.-Thompson, 1944, Kansas Geol. Survey, Bull. 52, p. t19-Thompson, 1945, idem., Bull. 60, p. 4).

Shell disc-shaped, periphery angular to rounded, usually completely planispiral, but some species may have an endothyroid juvenarium while others have only slight irregularities in coiling; volutions 4 to 7 , completely involute to slightly evolute; evolute species depressed or concave in polar area (umbilicate) and convex in involute forms; diameter one-fourth to one-half millimeter, axis usually one-fourth to onethird the diameter; spirotheca thin and believed to possess three walls, septa thin and long to short and thick ( $\Delta$-shaped); proloculum very minute; tunnel and chomata usually well developed.

The above generic description is essentially that of Thompson (1942, p. 404) but modified to include many subsequently described species, including those from the Kinkaid. The latter are entirely consistent generically with the Pennsylvanian forms and differ only in those minor structural features which are usually considered specific.

Millerella chesterensis Cooper, n. sp. Plate 19, figures 1-5

Shell very small, discoidal, periphery rounded; juvenarium endothyroid, essentially planispiral; spirotheca and septa thick, the latter almost $\Delta$-shaped in section, essentially straight, but directed forward making an angle of about $65^{\circ}$, on the average, with spirotheca; coiling elongate about juvenarium, resulting in an elongate peripheral outline in sagittal section; last volution partially evolute, forming a slightly umbilicate shell, the degree of concavity being unequal on opposite sides.

Data on shell measurements and septal counts is shown in table 1.

$M$. chesterensis differs from $M$. marblensis Thompson in its smaller size, shorter, thicker septa, larger tunnel angle, rounded periphery (see axial sections) and is almost completely involute. $M$. inflecta Thompson, although quite similar in axial section has thinner spirotheca and septa, greater regularity of coiling, a nonendothyroid juvenarium, and larger proloculum, diameter and form ratio.

Kinkaid formation, bed 5, JohnsonCounty, Illinois. 
Table 1.-Statistical Data For $M$. chesterensis, MeAsurements IN MiCRONS

\begin{tabular}{|c|c|c|c|c|c|c|c|c|c|c|c|c|c|c|c|}
\hline \multirow{2}{*}{ Spec. $^{1}$} & \multicolumn{5}{|c|}{ Septal Count } & \multirow{2}{*}{$\begin{array}{l}\text { Prol. } \\
\text { Diam. }\end{array}$} & \multirow{2}{*}{ L. } & \multirow{2}{*}{ IV. } & \multirow{2}{*}{ Ratio } & \multicolumn{5}{|c|}{ Ht. Volutions } & \multirow{2}{*}{$\begin{array}{l}\text { Tunne } \\
\text { Angle }\end{array}$} \\
\hline & 1 & 2 & 3 & 4 & 5 & & & & & 1 & 2 & 3 & 4 & 5 & \\
\hline $\begin{array}{l}1 \\
2 \\
3 \\
4\end{array}$ & $\begin{array}{l}\overline{-} \\
\overline{-}\end{array}$ & $\begin{array}{r}11 \\
9 \\
- \\
\end{array}$ & $\begin{array}{l}14 \\
13 \\
-\end{array}$ & $\begin{array}{l}18 \\
15 \\
-\end{array}$ & $\begin{array}{r}114 \\
17 \\
-\end{array}$ & 20 & $\begin{array}{l}\overline{-} \\
160 \\
140\end{array}$ & $\begin{array}{l}- \\
430 \\
350\end{array}$ & $\begin{array}{c}\overline{-} \\
1: \overline{0} .37 \\
1: 0.40\end{array}$ & $\begin{array}{l}\frac{13}{13} \\
13\end{array}$ & $\begin{array}{l}20 \\
20 \\
40 \\
20\end{array}$ & $\begin{array}{l}27 \\
27 \\
53 \\
27\end{array}$ & $\begin{array}{l}40 \\
40 \\
60 \\
40\end{array}$ & $\begin{array}{l}-\overline{53} \\
61 \\
60\end{array}$ & $\begin{array}{l}21^{\circ} \\
21^{\circ}\end{array}$ \\
\hline
\end{tabular}

1 Specimens 1 and 2 are sagittal sections, 3 and 4 are axial sections. Specimen 1 is illustrated in pl. 19 , figs. 1,$5 ; 2$, fig. 4 ; 3 , fig. 4 ; and 4 , fig. 2 .

Millerella kinkaidensis Cooper, n. sp. Plate 19, figures 9, 11

Shell small, discoidal; periphery subrounded, involute, and only slightly umbilicate; walls thick, septa short, thick and slightly curved; chambers small and about as wide as high (see sagittal section); prolo-
Kinkaid formation, bed 5, Johnson County, Illinois.

\section{Millerella Zelleri Cooper, n. sp. Plate 19 , figures 6-8}

Shell very minute, regularly coiled, septa very short, thick, tapered, closely spaced,

Table 2.-Statistical Data For $M$. kinkaidensis, Measurements IN Microns

\begin{tabular}{|c|c|c|c|c|c|c|c|c|c|c|c|c|c|c|}
\hline \multirow{2}{*}{ Spec. ${ }^{2}$} & \multicolumn{4}{|c|}{ Septal count } & \multirow{2}{*}{$\begin{array}{l}\text { Diam. } \\
\text { Proloc. }\end{array}$} & \multirow{2}{*}{ L. } & \multirow{2}{*}{ W. } & \multirow{2}{*}{ Ratio } & \multicolumn{5}{|c|}{$\mathrm{Ht}$. volutions } & \multirow{2}{*}{$\begin{array}{l}\text { Tunnel } \\
\text { angle }\end{array}$} \\
\hline & 1 & 2 & 3 & 4 & & & & & 1 & 2 & 3 & 4 & 5 & \\
\hline $\begin{array}{l}1 \\
2\end{array}$ & -8 & 13 & 16 & 20 & $\begin{array}{l}26 \\
23\end{array}$ & $\overline{18}$ & $\overline{36}$ & $1: \overline{0.50}$ & 13 & $\begin{array}{l}20 \\
20\end{array}$ & $\begin{array}{l}27 \\
33\end{array}$ & $\begin{array}{l}46 \\
46\end{array}$ & $\begin{array}{l}46 \\
74\end{array}$ & $\pm \overline{30^{\circ}}$ \\
\hline
\end{tabular}

${ }^{2}$ Specimen 1 is a sagittal section, 2 an axial section. Specimen 1 is shown on pl. 19, fig. 9; 2, fig. 11

culum relatively large; juvenarium endothyroid. Data on shell measurements and septal counts is shown in table 2.

$M$. kinkaidensis has a longer axis and larger proloculum than the other two Kinkaid species of Millerella. It differs from Pennsylvanian species much as the other Kinkaid species do. forming rather small chambers; periphery rounded; axial regions slightly and nearly equally umbilicate, completely involute; juvenarium endothyroid, but nevertheless the coiling is regular.

Data on shell measurements and septal counts is shown in table 3 .

$M$. zelleri is distinguished from $M$.

\section{Explanation of Plate 21}

Figs. 1-3-Balantoides reticulatus Croneis and Thurman. Dorsal, lateral and end views, $\times 50$. 4-6-Cornigella tuberculospinosa (Jones and Kirkby). Dorsal, lateral and end views, $\times$ (p. 84 .

7-8-Cornigella (p. 89)

7-8-Cornigella golcondensis (Croneis and Gale). Dorsal and lateral views, $\times 50$. (p. 90) 9-12-Ectodemites planus Cooper. Dorsal, ventral, lateral and end views, $\times 40$. (p. 84) 13-Beyrichiopsis thori Coryell and Johnson. Lateral view, $\times 40$.

14-16-Ectodemites tumidus Cooper. Dorsal, lateral and end views, $\times 40$.

17-18-Coryellites concava (Cooper). Dorsal and la teral views, $\times 40$.

19-22-Amphissites insignis Croneis and Thurman. Dorsal, ventral, lateral, and end views of two specimens (fig. 19, is a single valve), $\times 30$.

23-24-Coryellites portica Cooper, n. sp. Dorsal and lateral views, $\times 40$.

25-26-Bairdia golcondensis Croneis and Gale. Dorsal and lateral views, $\times 40$.

27-28-Bairdia attenuata Girty. Dorsal and lateral views, $\times 40$.

29-30-Bairdia impendere Cooper. Dorsal and lateral views, $\times 40$. 

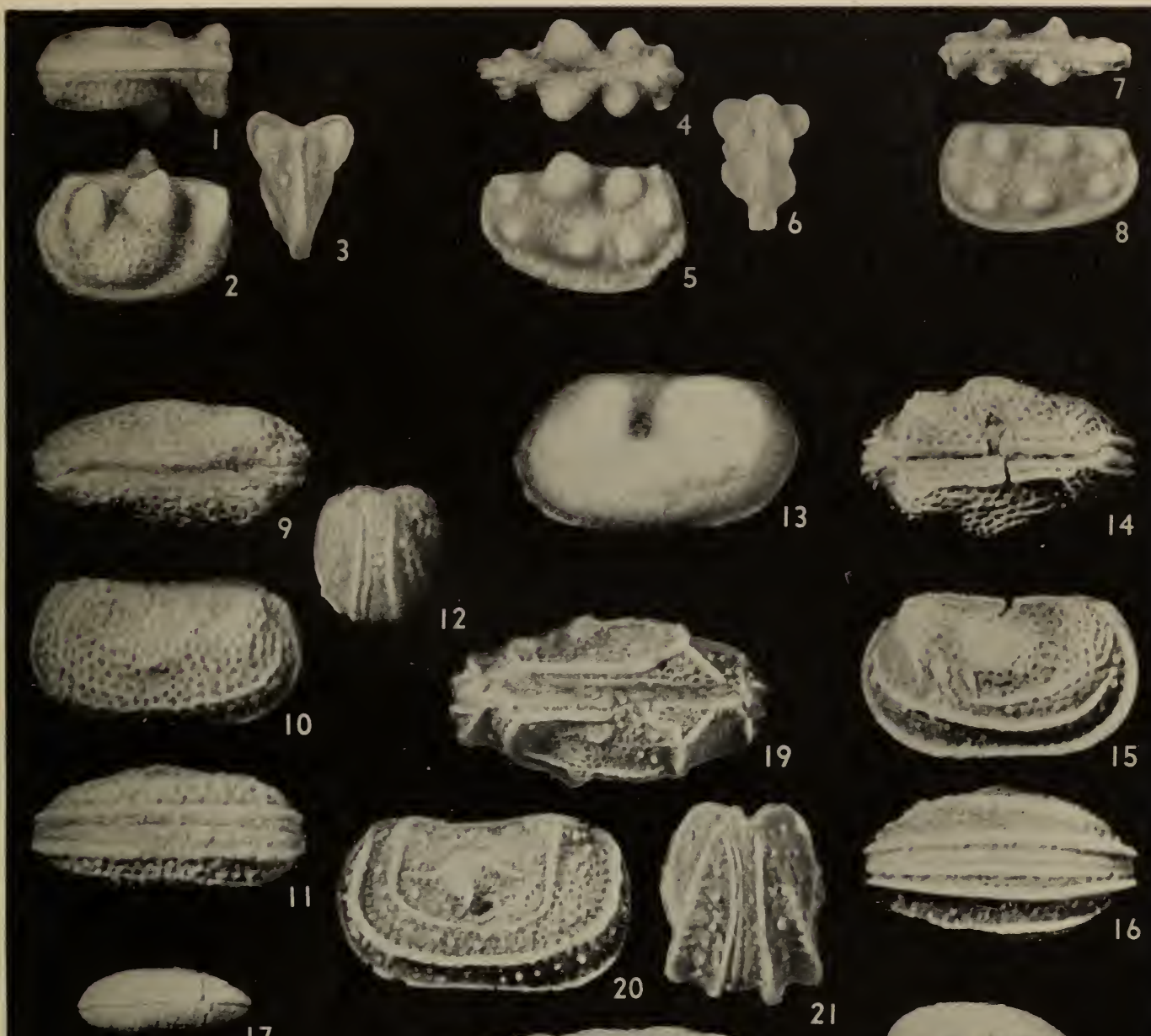

17
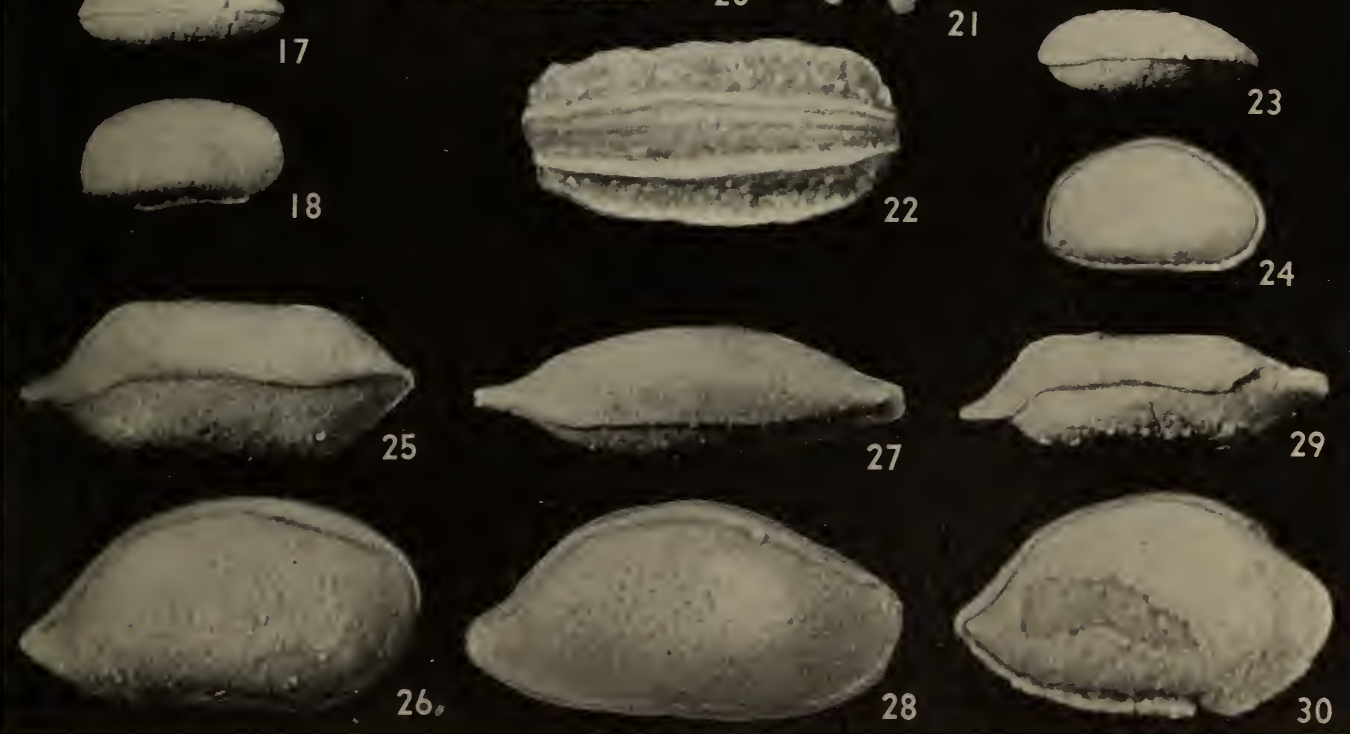

Cooper, Chester Ostracodes 


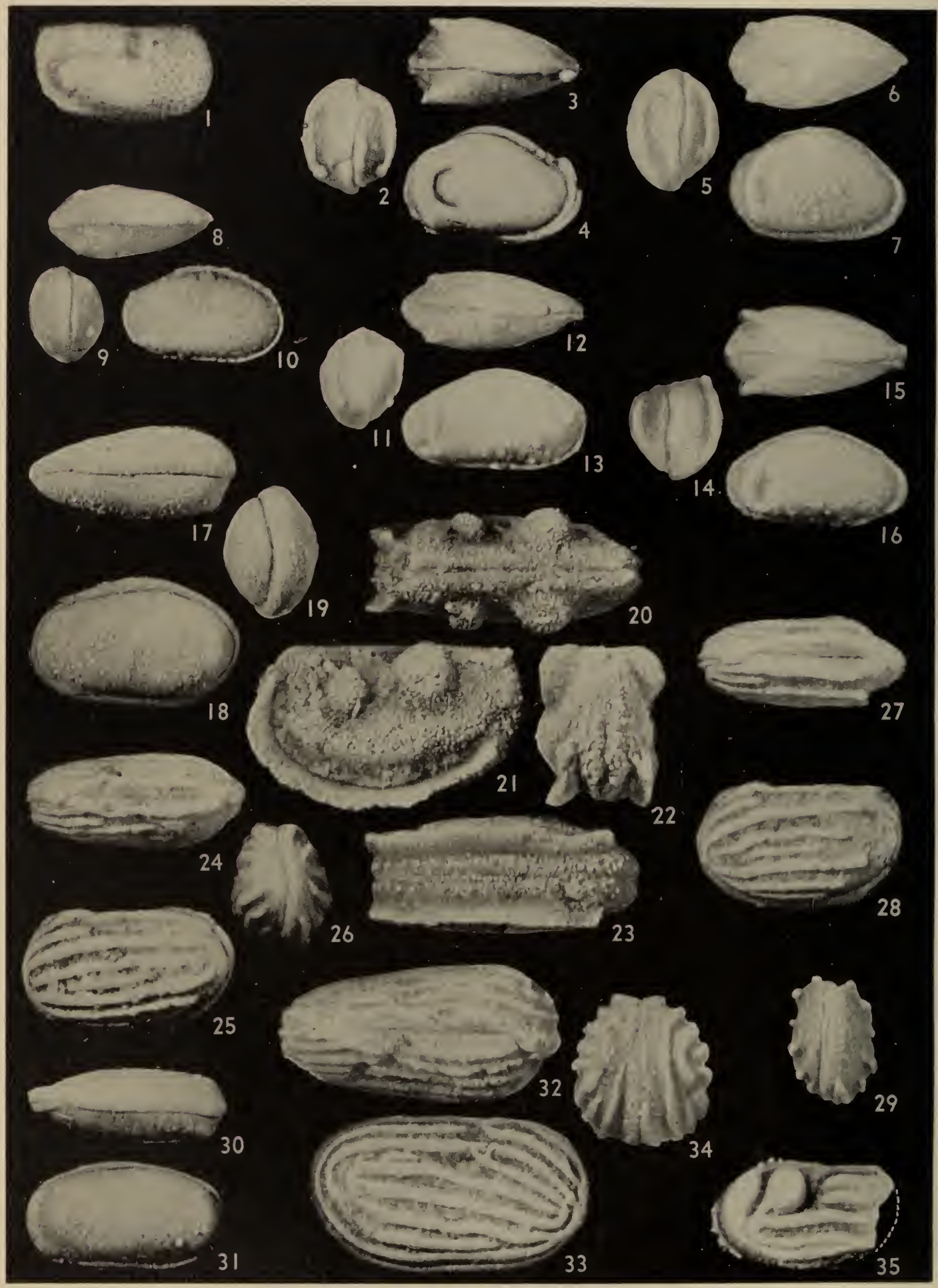

Cooper, Chester Ostracodes 
chesterensis by its thicker spirotheca, shorter and thicker septae, its regularity of coiling, and shorter axis. This is one of the smallest described species of Millerella.

Kinkaid formation, bed 5 , Johnson County, Illinois.

Family Ammodiscidae Rhumbler, 1895 Genus Glomospira Rzehak, 1888 Glomospira disca Cooper, n. sp. Plate 20, figure 18

Test minute, free, early volutions irregularly coiled, but tending to lie within
Genus Trepeilopsis Cushman and Waters, 1928

TREPEILOPSIS MISSISSIPPIANA Cooper, n. $\mathrm{sp}$. Plate 20, figures 34-41

Test attached to Productus spines or free, coiled in a tight conical spiral in early volutions, later becoming a cylindrical coil, finally the tube bends down across the spiral coils in a broadly curved manner that is roughly S-shaped; aperture at end of tube, wide, somewhat flared.

Length (holotype), $0.52 \mathrm{~mm}$.; diameter of tube in last whorl, $0.05 \mathrm{~mm}$; width of aperture, $0.056 \mathrm{~mm}$.

Table 3.-Statistical Data for $M$. zelleri, Measurements IN MICRONS

\begin{tabular}{|c|c|c|c|c|c|c|c|c|c|c|c|c|c|c|}
\hline \multirow{2}{*}{ Spec. $^{3}$} & \multicolumn{4}{|c|}{ Septal count } & \multirow{2}{*}{$\begin{array}{l}\text { Diam. } \\
\text { Proloc. }\end{array}$} & \multirow{2}{*}{ L. } & \multirow{2}{*}{ W. } & \multirow{2}{*}{ Ratio } & \multicolumn{5}{|c|}{ Ht. volutions } & \multirow{2}{*}{$\begin{array}{l}\text { Tunnel } \\
\text { angle }\end{array}$} \\
\hline & 1 & 2 & 3 & 4 & & & & & 1 & 2 & 3 & 4 & 5 & \\
\hline $\begin{array}{l}1 \\
2 \\
3\end{array}$ & $\begin{array}{r}11 \\
9 \\
\end{array}$ & $\begin{array}{l}14 \\
11 \\
\end{array}$ & $\begin{array}{l}16 \\
13 \\
\end{array}$ & $\begin{array}{l}18 \\
16 \\
\end{array}$ & $\begin{array}{l}20 \\
20 \\
23\end{array}$ & $\overline{-}$ & $\bar{z}$ & $\frac{\overline{-}}{1: \overline{0} .36}$ & $\begin{array}{l}13 \\
13 \\
13\end{array}$ & $\begin{array}{l}20 \\
27 \\
20\end{array}$ & $\begin{array}{l}27 \\
33 \\
33\end{array}$ & $\begin{array}{l}40 \\
40 \\
40\end{array}$ & $\begin{array}{l}46 \\
53 \\
46\end{array}$ & $\overline{C a \cdot 10^{\circ}}$ \\
\hline
\end{tabular}

${ }^{3}$ Specimens 1 and 2 are sagittal sections, and 3 are axial section. Specimen 1 is shown on pl. 19, fig. 8; 2 , fig. 6 , and 3 , fig. 7 .

plane of the last coil; tube increases regularly in diameter.

Diameter, $0.23 \mathrm{~mm}$; thickness, $0.12 \mathrm{~mm}$.

G. disca is smaller and more regularly coiled than $G$. siluriana Ireland, nor is the coiling so irregularly developed as in $G$. diversa Cushman and Waters.

Kinkaid formation, beds 5, 6, Johnson County, Illinois.
$T$. mississippiana differs from $S$. grandis Cushman and Waters by the marked curvature of the latter portion of the tube and from T. spirans (Cushman and Waters) by the flaring aperture. It can be separated from an undescribed Kinderhook species by the smaller size, tighter coiling, and the long taper of the latter.

\section{Explanation of Plate 22}

FIGs. $1-$ Kirkbyella quadrata Croneis and Gutke. Lateral view, $\times 50$.

2-4-Healdia sulcata Cooper $\mathrm{n}$. sp. Dorsal, lateral and end views of holotype, $\times 50$.

5-7-Healdia caneyensis Harlton. Dorsal, lateral and end views, $\times 50$.

8-10-Healdia aequabilis Cooper. Dorsal, lateral and end views, $\times 40$.

14-16-Healdia tenuicosta Cooper. Dorsal, lateral and end views, $\times 50$

17-19-Cavellina ovatiformis (Ulrich). Dorsal, lateral and end views, $\times 30$.

20-23-Hollinella radiata (Jones and Kirkby). Dorsal, lateral, ventral and end views, $\times 30$.

24-26-Glyptopleura circumcostata Cooper. Dorsal, lateral, and end views, $\times 40$.

27-29-Glyptopleura varians Croneis and Funkhouser, $\times 40$. 32, 34, Dorsal and end views 33. Lateral view of left valve of another specimen.

30-31-Cavellina librata Cooper. Dorsal and lateral views, $\times 40$.

32-34-Glyptopleura similis Croneis and Funkhouser. Dorsal lateral and end views, $\times 40$.

$35-$ Glyptopleurina iniqua Cooper. Lateral view of broken valve, $\times 40$. 


\section{Family Endothyidide Rhumbler, 1895 Genus Endothyra Phillips, 1845}

A great variety of species has been assigned to this genus by various workers in this country and abroad, forms ranging from the almost completely evolute $E$. gallowayi Thomas, discoid forms such as $E$. ammonoides Brady and E. subtilissima Brady, to such involute species as E. globula (d'Eichwald). Many intermediate forms with varying degrees of involution exist, such as E. ameradaensis Harlton and E. media Waters. Others, partially evolute on one side and involute on the other include the well-known E. baileyi (Hall) and the genotype species, E. bowmani Phillips. The habit of coiling is also extremely variable, as shown by the regular planispiral of the very flat species to the very great excentricity of thick, bulbous forms exemplified by E. baileyi. However, the heterogeneity of the latter species is not so marked as was first supposed, as shown by Scott, Zeller and Nodine (1946), who demonstrate that it has a definite axis of coiling for each half volution. Several species now classified with Endothyra probably should be listed with the primitive fusuline Millerella Thompsor: (1942), such as E. radiata Brady, E. globula (d'Eichwald) (Harlton, 1927) and possibly E. ornata Brady to judge from its sagittal section.

\section{Endothyra acuta Cooper, n. sp. Plate 20, figures 24, 30}

Shell medium sized, 8 chambers in last volution; periphery rounded; chambers large and somewhat arched at periphery due to deeply incised sutures as seen in lateral outline; septal angle somewhat less than normal, giving a "backward swing" appearance, especially in last three or four chambers; slightly biumbilicate, the left side being more evolute; apertural face abrupt, not in a plane normal to axis of coiling because the right side of the arch around the aperture has developed faster than the left, making it possible to view aperture from the left side.

Greatest diameter (holotype), $c a .0 .56$ mm.; diameter, last chamber, ca. $0.20 \mathrm{~mm}$.; axial thickness, $c a .0 .19 \mathrm{~mm}$. (These dimensions are approximate as last chamber of holotype is crushed.)
E. acuta resembles $E$. whitesidei Galloway and Ryniker in shape of chambers, but lacks the marked evolute character of the latter. It also has a larger aperture and consequently a higher apertural face than the Pennsylvanian species.

Kinkaid formation, beds 4 and 5, Johnson County, Illinois.

Endothyra excentralis Cooper, n. sp. Plate 20, figures 19-23

Shell small, thick, 6 to 8 chambers in last volution; periphery rounded; chambers bulbous, especially the final one which is much thicker proportionally than the others; sutures distinct and incised; right side completely involute, left somewhat umbilicate; aperture a crescent-shaped slit located at the base of chamber, extending from the center down the umbilicate side.

Greatest diameter (holotype), $0.48 \mathrm{~mm}$; diameter last chamber, $0.26 \mathrm{~mm}$; axial thickness, $0.16 \mathrm{~mm}$.

$E$. excentra is similar to $E$. media Waters, E. ovata Waters, E. distenta H. J. Plummer, and $E$. rothrocki Harlton, but the shape of the aperture differentiates it from the first three and the central position of the aperture distinguishes the latter.

Kinkaid formation, beds 4 and 5, Johnson County, Illinois.

Family Astrorhizidae Brady, 1881

Genus Hyperammina Brady, 1878

Hyperammina cf. H. Elongata

Clavatula Howchin

Plate 20, figures 25-27

Hyperammina elongata clavatula Howchin, 1888, Royal Micr. Soc. Jour., p. 535, pl. 8, figs. 1, 2; Mississippian limestones of England.-Harlton, 1927, Jour. Paleontology, vol. 1, p. 16, pl. 1, figs. 1a, b; Upper Caney shale, Oklahoma.Harlton, 1933, idem, vol. 7, p. 8, pl. 1, figs. 1ae; John Valley shale, Okla.

The Kinkaid specimens cannot be distinguished from those occurring above and below the Mississippian-Pennsylvanian boundary in Oklahoma. However, - they lack the pointed proloculum of $H$. elegantissima H. J. Plummer, and $H$. spinescens Cushman and Waters and the globular proloculum of $I I$. bulbosa Cushman and Waters, reported by Mrs. H. J. Plummer from younger beds in Texas. 
Kinkaid formation, hed 7, Johnson County, Illinois.

Hyperammina cf. H. Glabra Cushman and Waters

Plate 20, figure 33

Hyperammina glabra Cushman and Waters, 1927, Cushman Lab. Foram. Research Contr., vol. 3 , p. 146 , pl. 26 , fig. 1 ; upper Strawn, Texas.-Cushman and Waters, 1930, Texas Univ. Bull. 3019, p. 33, pl. 2, figs. 1-3; Cisco group, Texas.

This Kinkaid specimen seems to be similar in most respects to the species from the Pennsylvanian of Texas in its small proloculum with a slight constriction above it, followed by a long gradually widening tube that is straight to slightly bowed.

Kinkaid formation, bed 4, Johnson County, Illinois.

\section{Hyperammina sp.}

Plate 20, figures 28, 29

The two large fragments apparently belong to this genus but the absence of a proloculum precludes specific designation.

Kinkaid formation, bed 7, Johnson County, Illinois.

Family Textularidae d'Orbigny, 1846 Genus Palaeotextularia Schubert, 1920 Palaeotextularia asper Cooper, n. sp. Plate 20, figures 31,32

Test biserial, chambers flat, elongate, increasing in size in a regular manner, with sutures parallel and indistinct; aperture a low, central slit at base of apertural face; walls granular.

The biserial arrangement is similar to Palaeotextularia sp. Harlton from the Johns Valley shale, but the Kinkaid form is more tenuous and has a more slender aperture. $P$. asper is more stocky than $P$. grahamensis (Cushman and Waters) and has a more elongate aperture but is without the globular chambers of the latter.

Kinkaid formation, bed 5, Johnson County, Illinois.

\section{Subclass Ostracoda I atreille, 1801}

All ostracode species of this fauna are illustrated (pls. 21-23) but descriptions are presented only for those that are new.
Descriptions of the others may be obtained readily from the published reports listed in the references. Several short discussions indicate the differentiation of some previously described Kinkaid species from similar Pennsylvanian forms.

Family Bairdiddae Sars, 1887

Genus Coryellites Kellett, 1936

Coryellites concava (Cooper)

Plate 21, figures 17,18

Bythocypris concava Cooper, 1941, Illinois Geol. Survey Rept. Inv. 77, p. 28, pl. 3, figs. 3-6; Vienna, Menard and Kinkaid formations, Illinois.

This species described from the upper Chester should have been classified under Coryellites for the reasons set forth in the report on the Pennsylvanian ostracodes of Illinois (Cooper, 1946, p. 55).

Coryellites portica Cooper n. sp. Plate 21, figures 23, 24

Carapace ovate, dorsal and ventral margins unequally arched; ventral margin straight; ends rounded; posterior considerably higher and thicker than anterior; overlap moderate and uniform around all margins.

Length, $0.57 \mathrm{~mm}$.; height $0.35 \mathrm{~mm}$.; thickness, $0.23 \mathrm{~mm}$.; form ratio, 1.63 .

C. portica resembles C. subelliptica (Upson) and C. johnsoni (Upson) but is more highly arched and has a more nearly perpendicular posterior margin than these Pennsylvanian species.

Kinkaid formation, bed 1, Johnson County, Illinois.

Family Drepanellidae Swartz, 1936

Genus Cornigella Warthin, 1930

Cornigella tuberculospinosa (Jones and Kirkby)

Plate 21, figures 4-6

(For synonomy see Cooper, 1946, p. 78.)

This multinodose form appears in several Chester and Pennsylvanian ostracode zones. The Kinkaid specimens are indistinguishable from those of the Pennsylvanian, typically possessing an elongate, but blunt spinelike node anterodorsally, behind which is another similar but shorter node. All other nodes (there is usually a total of 6 to 8 ) are 
smaller than two near the dorsum. The only other Chester species, C. golcondensis (Croneis and Gale), is considerably more elongate.

Kinkaid formation, bed 1, Johnson County, Illinois

Genus VARIX Cooper, n. gen.

Carapace subovate, cardinal angles subequal, with well-defined "swing," free margin (and part of dorsal margin) bordered by a well-defined ridge, central portion marked by irregular, more or less continuous ridges.

\section{Genotype, Varix propria Cooper n. sp.}

Varix conforms to other genera of the family in its shape and bordering ridge, but the irregularity of its other ornamental features distinguishes it from its near relatives.

\section{VARIX PROPRIA Cooper, n. sp. \\ Plate 23, figures 12-14}

Carapace elongate, subovate, hinge line straight, ends rounded, ventral margin slightly concave; cardinal angles very unequal, the anterior being about $90^{\circ}$, the posterior markedly acute; free margins and part of dorsal margin bordered by a prominent ridge of uniform height and width; central portion of shell marked by an irregular ridge of similar character, subrectangular to subelliptical, the axis of "ellipse" parallel to ventral margin, with a continuation of the ridge inside the "ellipse"; one side of the central portion of the ridge develops into a loop anterior to a shallow circular pit located near midlength; the loop ends posterior to the pit in a small circular node; near the center of the anterodorsal margin the outer loop rises above the hinge line; articulation simple and apparently without overlap.

Length (of holotype), $0.49 \mathrm{~mm}$; height, $0.38 \mathrm{~mm}$.; form ratio, 1.44 .

Kinkaid formation, bed 5, Johnson County, Illinois.

Family Glyptopleuridae Girty, 1910

Genus Glyptopleura Girty, 1910

Giyptopleura similis Croneis and Funkhouser

Plate 22, figures $32-34$

Glyptopleura similis Croneis and Funkhouser, 1938, Denison Univ. Bull., Jour. Sci. Lab., vol.
33, p. 352, pl. 10, fig. 4.-Cooper, 1941, pl. 7, figs. 23, 24; Clore formation, Illineis.

This species has a rib pattern somewhat similar to $G$. coryelli Harlton in that the rib which is just above the pit bifurcates anteriorly. However, the two species may be distinguished by their differences in lateral outline, the Pennsylvanian species being more quadrate, or not as subelliptical as in G. similis.

Kinkaid formation, beds 4-6, Johnson County, Illinois.

Family Healdiddae Harlton, 1933

Genus Healdia Roundy, 1926

Healdia sulcata Cooper, n. sp.

Plates 22, figures 2-4

Carapace short, tumid, lateral outline subelliptical; dorsal margin strongly convex, ventral margin nearly straight; posterior ridge curved and directed strongly toward posterior, rising but little above curvature of shell as seen in dorsal view; ridge bordered on anterior side by a deeply incised semicircular furrow of uniform width; overlap prominent around dorsal and ventral margins, each valve developed at ends to produce a slightly incised articulation posteriorly and in irregular flare or "frill" on anterior; surface smooth except for furrow.

Length, $0.52 \mathrm{~mm}$; height, $0.36 \mathrm{~mm}$; thickness, $0.29 \mathrm{~mm}$.

II. sulcata is readily distinguished by the unusual furrow in front of the usual posterior ridge which is typical of the genus. However, this should not be confused with the depressed area of Incisurella or the trough formed by a row of pits in Cribroconcha. Except for the furrow $H$. sulcata is much like many other species such as $H$. ornata Morey and $H$. ovoidea Cooper from the Chester and $H$. ehlersi Bradfield and $H$. nucleolata Knight from the Pennsylvanian.

Kinkaid formation, beds $4-6$, Johnson County, Illinois

\section{Family KIRKBYidae Ulrich and} Bassler, 1923

Genus Ectodemites Cooper, 1941 Ectodemites tumidus Cooper Plate 21, figures 14-16

Ectodemites tumidus Cooper, 1941, Illinois Greol. Survey Rept. Inv. 77, p. 51, pl. 10, figs. 1-3.

E. tumidus, known only from the Kinkaid, 
resembles E. plummeri Cooper from the Marble Falls (Texas) and Ferdinand (Indiana) formations of Morrow age, in both size and general shape. However, the ridges of the younger species are more prominent, the reticulations coarser, and the kirkbyan pit larger and almost centered under the medial node. The inner ridge of E. tumidus is especially prominent compared to that of E. plummeri.

Kinkaid formation, beds 4-6, Johnson County, Illinois.

\section{Family Kloedenellidae Ulrich and Bassler, 1923 \\ Genus Sansabella Roundy, 1926 \\ SANSABElla HARRISI Croneis and Funkhouser \\ Plate 23, figures 26-29}

Sansabella harrisi Croneis and Funkhouser, 1938, Denison Univ. Bull., Jour. Sci. Lab., vol. 33, p. 334 , pl. 9, figs. 7, 8; Clore formation.Cooper, 1941, Illinois Geol. Survey, Rept. Inv. 77 , p. 60 , pl. 13, figs. 15, 16; Clore and Kinkaid formations.

Sansabella thurmani Croneis and Funkhouser, 1938, op. cit., p. 336, pl. 9, figs. 11, 12; Clore formation.

Like many other species of Sansabella this one is found in two forms, one of which is the mirror image of the other. It resembles $S$. carbonaria, from the Missouri series, but is not so elongate, nor does it have the angulated line of concrescence of the Pennsylvanian species. The younger form also has a more prominent pit.

Kinkaid formation, bed 4, Johnson County, Illinois.

\section{Genus Sargentina Coryell and} Johnson, 1939

SaRgentina CRassimarginata (Croneis and Thurman)

Plate 23, figures 30-34

Sulcella crassimarginata Croneis and Thurman, 1938, Denison Univ. Bull., Jour. Sci. Lab., vol. 33 , p. 328, pl. 7, figs. 15, 16; Kinkaid formation. Sargentina crassimarginata, Cooper, 1941, Illinois Geol. Survey, Rept. Inv. 77, p. 39, pl. 6, figs. 9, 10; Kinkaid formation.

This common Kinkaid species is somewhat larger than representatives of the genus which occur rather high in the Pennsylvanian system. S. tumida Cooper from the "Centralia" zone may be distinguished by its greater ellipticity and curved hinge- line and $S$. elongata Cooper from the Little Vermilion is more elongated and has a hinge margin that is more nearly straight. Kinkaid formation, bed 4, Johnson County, Illinois.

Conodonts Pander, 1856

Genus Cavusgnathus Harris and Hollingsworth, 1933

Cavusgnathus CRistata Branson and Mehl Plate 20, figures 4-10

Cavusgnathus cristata Branson and Mehl, 1940 Denison Univ. Bull., Jour. Sci. Lab., vol. 35, p. 177 , pl. 5, figs. 26-31; Caney shale, Oklahoma.

This large species with its high platform and deep trough, and the "cockscomb" development on the oral side is confined to Chester and younger formations. It is much larger than the Pennsylvanian species, and there appears to be little difference between Caney and Kinkaid specimens, except that those from the latter are slightly larger (1.5 $\mathrm{mm}$. and $2.0 \mathrm{~mm}$., respectively).

Kinkaid formation, bed 4, Johnson County, Illinois.

\section{Genus Hindeodella Ulrich and Bassler, 1926 HiNdEODELLA sp. Plate 20, figures, 11-13}

This genus is represented only by fragments of bars which are not specifically determinable. However, three types of dentition are represented: 1 , Large denticles alternating with groups of three smaller ones, and slightly inclined (fig. 11); 2, large denticles alternating with single small denticles, all sharply inclined (fig. 12); and 3 , all large denticles sharply inclined to bar (fig. 13). Not enough specimens have been obtained to determine characters that might distinguish them from other Carboniferous species.

Kinkaid formation, beds 1, 4, 6, Johnson County, Illinois.

Genus Ligonodina Ulrich and Bassler, 1926

Ligonodina cf. L. LEvis Branson and Mehl

Plate 20, figure 17

Ligonodina levis Branson and Mehl, 1941, Denison Univ. Bull., Jour. Sci. Lab., vol. 35, 
p. 185 , pl. 6, fig. 10; Keokuk formation, Missouri.

Although fragmentary, the Kinkaid specimen conforms to this Keokuk species with respect to the fairly heavy, slightly curved cusp, thin bar with thin, discrete denticles; projection probably slight judging from the scar remaining.

Kinkaid formation, beds, 5, 6, Johnson County, Illinois.

Genus Prioniodus Pander, 1856

Prioniodus Scitulus Branson and Mehl Plate 20, figures 1-3

Prioniodus scitulus Branson and Mehl, 1941,

Denison Univ. Bull., Jour. Sci. Lab., vol. 35,

p. 173, pl. 5, figs. 5, 6; Caney shale, Oklahoma.

This species with its erect cusp, lensshaped in cross section, with large appressed denticles, free in upper half, and fluted projection, is typically Mississippian.

Kinkaid formation, beds 1, 4-6, Johnson County, Illinois

\section{Genus Taphrognathus Branson and Mehl, 1941}

TAPHROGNATHUS VARIANS Branson and Mehl

Plate 20, figures 14-16

Taphrognathus varians Branson and Mehl, 1941, Denison Univ. Bull., Jour. Sci. Lab., vol. 35 p. 182, pl. 6, figs. 27-41; Keokuk formation, Missouri.

The Kinkaid species is similar in all respects to that from the Keokuk, e.g., in size, shape of bar both orally and aborally, and shape and dentition of the blade.

Kinkaid formation, bed 1, Johnson County, Illinois

\section{REFERENCES}

Bradfield, H. H., 1935, Pennsylvanian Ostracoda of the Ardmore basin, Oklahoma: Bull. Am. Paleontology, vol. 22, no. 73, pls. 1-13.

Brady, H. B., 1876, A monograph of Carboniferous and Permian Foraminifera (the genus Fusulina excepted): Paleontographical Soc., vol. 30 , pp. 1-166, pls. 1-12.

Branson, E. B. and Mehl, M. G., 1941, Caney conodonts of Upper Mississippian age $\cdot$ Denison Univ. Bull. Jour. Sci. Lab., vol. 35, pp. 167178 , pl. 5 .

- 1941, Conodonts from the Keokuk formation: Idem, pp. 179-188, pl. 6.

Cooper, Chalmer L., 1942, Chester ostracodes of Illinois: Illinois Geol. Survey, Rept. Inv. 77.

_ 1946, Pennsylvanian ostracodes of Illinois: Illinois Geol. Survey Bull 70.

Coryell, H. N. and Johnson, Samuel C., 1939, Ostracoda oi the Clore limestone: Jour. Paleontology, vol. 13, pp. 214-224, pls. 25, 26.

Croneis, Carey and Funkhouser, Harold J., 1938, New ostracodes from the Clore formation: Denison Univ. Bull., Jour. Sci. Lab., vol 33 , pp. 313-360, pls. 9, 10.

Croneis, Carey and Gale, Arthur S., 1938, New ostracodes from the Golconda formation: Idem, pp. 251-295, pls. 5, 6.

Croneis, Carey and Thurman, Franklin A. 1938, New ostracodes from the Kinkaid formation: Idem, vol. 33, pp. 297-330, pls. 7, 8 .

Cushman, J. A. and Waters, J. A., 1927, Pennsylvanian Foraminifera from Michigan: Cushman Lab. Foram. Research Contr., vol. 3, pp. 107-110, pl. 22.

- 1928a, Some Foraminifera from the Pennsylvanian and Permian of Texas: Idem, vol. 4 pp. 31-55, pls. 4-7.

\section{Explanation of Plate 23}

Figs. 1-4-Monoceratina celsalobata Cooper. Dorsal and lateral views, $\times 50$.

5-8-Monoceratina furcula Croneis and Gale. Dorsal, lateral, ventral and end views, $\times 50$.

9-11-Glyptopleura tyri Coryell and Johnson. Dorsal, lateral and end views, $\times 40$. (p. 85)

12-14-Varix propria Cooper, n. gen., n. sp. 12, 13, Interior and lateral views of holotype; 14 , lateral view of a paratype, $\times 50$.

15-17-Perprimitia funkhouser $i$ Croneis and Thurman, Dorsal, lateral and end views, $\times 40$.

18-20-Paraparchites nicklesi (Ulrich) Dorsal, lateral and end views, $\times 40$.

21-24-Neokloedenella prima Croneis and Funkhouser. Dorsal, lateral, ventral and end views, $\times 30$.

25-Polytylites quincollinus (Harlton) Lateral view, $\times 40$.

26-29-Sansabella harrisi Croneis and Funkhouser. Dorsal and lateral views of reversed forms, $\times 40$.

30-34-Sargentina crassimarginata Croneis and Thurman: Dorsal, lateral, ventral (right and left valves) and end views, $\times 40$. 




Cooper, Chester Ostracodes 

- 1928b, Additional Cisco Foraminifera from Texas: Idem, vol. 4, pp. 62-67, pl. 8 .

- 1928c, Upper Paleozoic Foraminifera from Sutton County, Texas: Jour. Paleontology, vol. 2, pp. 358-371, pls. 47-49.

- 1930, Foraminifera of the Cisco group of Texas: Texas Univ. Bull. 3019, pp. 22-81, pls. 2-12.

Dunbar, Carl O. and Henbest, Lloyd G., 1942, Pennsylvanian Fusulinidae of Illinois: Illinois Geol. Survey Bull. 67.

Easton, WM. H., 1945, Kinkaid corals from Illinois. Jour. Paleontology, vol. 19, no. 4, pp. 383389, 8 figs. (Reprinted as Illinois Geol. Survey Rept. Inv. 113).

Galloway, J. J., 1933, A manual of Foraminifera: Principia Press, Bloomington, Ind.

Galloway, J. J. and Ryniker, C., 1930, Foraminifera from the Atoka formation of Oklahoma: Oklahoma Geol. Survey, Cir. 20.

Girty, George H., 1910, New Carboniferous fossils from the Fayetteville shale of Arkansas: New York Acad. Sci. Ann. vol. 20, no. 3, pt. 2, pp. 232-236.

Hall, J., 1858, Descriptions of new species of fossils from the Carboniferous limestone of Indiana and Illinois: Albany Ins1. Trans., vol. 4, pp. 1-35.

Harlton, B. H., 1927, Some Pennsylvanian Ostracoda of the Glenn and Hoxbar formations of southern Oklahoma and of the upper part of the Cisco formation of northern Texas: Jour. Paleontology, vol. 1, pp. 203-212, pls. 32-33.

- 1928a, Pennsylvanian Foraminifera of Oklahoma and Texas; Iden, vol. 1, pp. 306-310, pls. 52,53 .

-, 1928b, Pennsylvanian ostracodes of Oklahoma and Texas: Idem, vol. 2, pp. 132-141, pl. 21.

, 1929a, Pennsylvanian Ostracoda from Menard County, Texas: Texas Univ. Bull. 2901, pp. 139-161, pls. 1-4.

_ 1929b, Some Upper Mississippian (Fayetteville) and Lower Pennsylvanian (WapanuckaMorrow) Ostracoda of Oklahoma and Arkansas: Am. Jour. Sci., ser. 5, vol. 18, no. 105, pp. 254-270, pls. 1,2 .

- 1933, Micropaleontology of the Pennsylvanian Johns Valley shale of the Ouachita Mountains, Oklahoma, and its relationship to the Mississippian Caney shale: Jour. Paleontology, vol. 7, pp. 3-29, vols. 1-7.

Harris, R. W. and Hollingsworth, R. V., 1933, New Pennsylvanian conodonts from Oklahoma: Am. Jour. Sci., ser. 5, vol. 25, pp. 193204 , pl. 1.

Henbest, Lloyd G., 1946, The Morrow group, Pennsylvanian, of Washington County, Arkansas (abst.): Am. Assoc. Petroleum Geologists, Program 1946 Annual Meeting, p. 57.

IRELAND, H. A., 1939, Devonian and Silurian Foraminifera from Oklahoma: Jour. Paleontology, vol. 13, pp. 190-202.

Knight, J. B., 1928, Some Pennsylvanian ostracodes from the Henryetta formation of eastern Missouri: Jour. Paleontology, vol. 2, pp. 229267 , pls. $30-34$; pp. $318-336$, pls. 43,44 .
LAmar, J. E., 1925, Geology and mineral resources of the Carbondale quadrangle: Illinois Geol. Survey Bull. 48.

MöLlER, V., 1878, Ueber Fusulinen und ähnliche Foraminifera formen des russischen Kohlenkalks: Neues Jahrb. f. Min., Jahrb. 1877, pp. 138-146.

-1878 , Die Spiral-gewundenen Foraminiferen des russischen Kohlenkalks: Mém. Acad. Imp. Sci., St. Petersburg, ser. 7, vol. 25, no. 9, pp. 1-147, pls. 1-15.

- 1879, Die Foraminiferen des russischen Kohlenkalks· Idem, vol. 27, no. 5, pp. 1-131, pls. $1-7$.

Morey, Phillip S., 1935, Ostracoda from the Amsden formation of Wyoming. Jour. Paleontology, vol. 9, pp. 474-482, pl. 54.

D'Orbigny, A. D., 1826, Tableau Méthodique de la Classe des Céphalopodes: Annales sci. nat., vol. 7 , pp. $131,245-314$, pls. 10-17.

Pander, O. H., 1856, Monographie der fossilen Fische des silurischen Systems der RussichBaltischen Gouvernments, St. Petersburg, pp. $1-9$, pls.

Phillips, J., 1845, Proc. Yorkshire Geol. and Poly. Soc. II, p. 277, pl. 7.

Plummer, Helen J., Smaller Foraminifera in the Marble Falls, Smithwick and lower Strawn strata around the Llano uplift in Texas: Texas Univ. Bull. 4401, pp. 209-271, pls. 15-17.

Rhumbler, L., 1895, Entwurf eines Natürlichen Systems der Thalamophoren: Nachr. K. Gesell. Wiss. Göttingen, Math. -Phys. Kl., pp. 51-981.

RoTH, ROBERT, 1929, A revision of the ostracode genus Kirkbya and subgenus Amphissites: Wagner Free Inst. Sci. Publ. 1, pp. 1-55, pls. $1-3$.

Roundy, P. V., 1926, Mississippian formations of San Saba County, Texas: U. S. Geol. Survey, Prof. Paper 146, pp. 5-8, pl. 1.

RzEHAK, A., 1888, Verh., k.k. geol. Reichs., Wein, p. 191.

Scott, Harold W., Nodine, Doris and Zeller, EDWARD, 1946, Wall structure of Endothyra baileyi (abst.): Am. Assoc. Petroleum Greologists, Program 1946 meeting, p. 57.

Swartz, F. M., 1936, Revision of the Primitiidae and Beyrichiidae with new Ostracoda from the Lower Devonina of Pennsylvania: Jour. Paleontology, vol. 10, no. 7, pp. 541-586, pls. 78-89.

Thomas, A. O., 1931, Late Devonian Foraminifera from Iowa: Jour. Paleontology, vol. 5, pp. 40-41, pl. 7.

Thompson, M. L., 1942, New genera of Pennsylvanian fusulinids: Am. Jour. Sci., vol. 240, pp. 403-420, pls. $1-3$.

$\ldots, 1944$, Pennsylvanian Morrowan rocks and fusulinids of Kansas: Kansas Geol. Survey Bull. 52, pp. 409-431.

_- 1945, Pennsylvanian rocks and fusulinids of east Utah and northwest Colorado correlated with Kansas section: Idem, Bull. 60, pp. 17-84.

Ulrich, E. O. and BAssler, R. S., 1923, Maryland Grenl. Survey, Silurian volume, 794 pp., 27 figs. 67 pls. 
1926, A classification of the toothlike fossils, conodonts, with descriptions of American Devonian and Mississippian species: U. S. Nat. Mus. Proc., vol. 18, art. 12, pp. 1-63, pls. 1-12. WARThIN, A. S., JR., 1930, Micropaleontology of the Wetumka, Wewoka and Holdenville formations: Oklahoma Geol. Survey Bull. 53, pls. $1-7$.
WAters, J. A., 1927, A group of Foraminifera from the Dornick Hills formation of the Ardmore basin: Jour. Paleontology, vol. 1, pp. 129133 , pl. 22.

, 1928, A group of Foraminifera from the Canyon division of the Pennsylvanian formation in Texas: Idem, vol. 1, pp. 271-275, pl. 42. 

